\title{
Injury to murine airway epithelial cells by pollen enzymes
}

\author{
Zeenath Hassim, Sonia E Maronese, Rakesh K Kumar
}

\begin{abstract}
Background-Pollens are important triggers for asthma but the mechanism of sensitisation to their proteins remains poorly understood. The intrinsic protease activity of some allergens may contribute to sensitisation by disrupting the integrity of the airway epithelial barrier. Pollens release a variety of enzymes, including proteases, upon hydration. The hypothesis that such enzymes might be able to damage airway epithelial cells was therefore tested.
\end{abstract}

Methods-Diffusates from pollens of Lolium perenne (ryegrass), Poa pratensis (Kentucky bluegrass), Acacia longifolia (Sydney golden wattle), or Casuarina distyla (she-oak) were incubated with mouse tracheal epithelial cells in culture and cellular detachment was quantified using a methylene blue dye binding assay. Results-Diffusates prepared using $100 \mathrm{mg} / \mathrm{ml}$ of pollen caused detachment of $30-90 \%$ of airway epithelial cells in separate experiments. Within each experiment comparable detachment was observed with all diffusates tested, although total protein in the diffusates varied markedly between species. Viability of the cells recovered after exposure to Acacia diffusate was higher than after detachment by exposure to Lolium diffusate. Cellular detachment by all of the diffusates could be almost completely inhibited by addition of $10 \%$ serum. Aprotinin, an inhibitor of serine proteases, partially blocked activity in diffusates of Lolium pollen but not of Acacia pollen. In contrast, $\alpha_{1}$-protease inhibitor and secretory leucocyte protease inhibitor (SLPI) were not able to block the activity of either diffusate at concentrations which inhibited cellular detachment by trypsin.

Conclusions-Proteases released by pol-

Research Unit, School of Pathology,

University of New

South Wales, Sydney,

Australia 2052

Z Hassim

S E Maronese

R K Kumar

Correspondence to:

Dr R K Kumar.

Received 18 August 1997 Returned to authors 1 October 1997

Revised version received

30 December 1997

Accepted for publication

21 January 1997
Clinical asthma is usually related to underlying IgE mediated allergic inflammation. ${ }^{1}$ However, the mechanisms of sensitisation to inhaled allergens remain incompletely understood. Tight junctions between airway epithelial cells apparently constitute a physical barrier be- tween inhaled antigens and the immune system. Experimental evidence suggests that, if this barrier is breached at the time of initial exposure to antigen by concurrent infection or exposure to environmental pollutants, an $\operatorname{IgE}$ response is more likely to be induced. ${ }^{2}$ This may be a result of facilitated access of allergenic protein components to the subepithelial antigen presenting dendritic cells. ${ }^{3}$ In this context it is therefore noteworthy that at least some allergens have intrinsic enzymatic activity-for example, major house dust mite ${ }^{4}$ and cockroach $^{5}$ allergens exhibit protease activity. Exposure to such proteases in vitro causes epithelial detachment and increases the permeability of epithelial sheets and cultured monolayers of airway epithelium. ${ }^{6}$ These observations have led to the suggestion that disruption of intercellular junctions by the enzymatic activity of inhaled allergens might cause loss of integrity of the airway epithelial barrier in vivo and thus promote sensitisation to these antigens. ${ }^{4}{ }^{6}$

Airborne allergens derived from plant pollens are major triggers for asthma. ${ }^{7}$ However, information about whether these might function as proteases is lacking. ${ }^{8}$ Pollens do contain a variety of enzymes including proteases, and very high local concentrations of pollen solutes are likely to be achieved when pollen grains are deposited on mucosal surfaces because 20$25 \%$ of the pollen mass is released rapidly upon hydration. ${ }^{910}$ We hypothesised that proteases released by inhaled pollens might be able to damage the airway epithelium. To test this hypothesis, we investigated whether diffusates of potentially allergenic pollens were able to cause detachment of murine airway epithelial cells from their substratum in vitro.

\section{Methods}

PREPARATION OF POLLEN DIFFUSATES

Pollens of the allergenic species Lolium perenne (ryegrass), Poa pratensis (Kentucky bluegrass), and Acacia longifolia (Sydney golden wattle) were obtained from Bayer Australia, Sydney. Pollen of Casuarina distyla (she-oak) was collected in the Royal National Park, Sydney (with the assistance of Dr Peter Stricker, School of Biological Science, The University of New South Wales). Diffusates of the pollens were prepared under physiological conditions by thoroughly mixing the dry pollen with basal medium MCDB 201 (Sigma, St Louis, Missouri, USA) at ratios of $10-100 \mathrm{mg}$ pollen per $\mathrm{ml}$. The suspension was then incubated at $4^{\circ} \mathrm{C}$ for 30 minutes without further agitation, followed by centrifugation at $16000 \mathrm{~g}$ for eight minutes to pellet the pollen grains, and the 
Table 1 Cellular detachment activity and concentration of protein in diffusates of various pollens

\begin{tabular}{lllll}
\hline & Lolium & Poa & Acacia & Casuarina \\
\hline Detachment $(\%)^{\star}$ & $36.5(8.6)$ & $56.7(7.4)$ & $59.5(3.4)$ & $45.1(11.0)$ \\
Protein $(\mathrm{mg} / \mathrm{ml})$ & 4.6 & 6.1 & 0.8 & 2.0 \\
\hline
\end{tabular}

${ }^{\star}$ Calculated relative to the mean absorbance of wells incubated in basal medium. Diffusates were prepared at $100 \mathrm{mg}$ dry pollen per $\mathrm{ml}$ of medium. Data are mean (SE) of a single assay.

supernatants were used immediately. The protein content of an aliquot of each diffusate was measured using a dye binding assay (Bio-Rad, Sydney) with bovine serum albumin (0.1$1.6 \mathrm{mg} / \mathrm{ml}$ ) as the standard.

CULTURE OF MURINE AIRWAY EPITHELIAL CELLS Mouse airway epithelial cells were cultured from explants of tracheal tissue in serum-free medium as previously described. ${ }^{11}$ Briefly, fragments of tracheal tissue from 8-10 week old specific pathogen-free $\mathrm{BALB} / \mathrm{c}$ mice were cultured at $37^{\circ} \mathrm{C}$ in an atmosphere of $2 \% \mathrm{CO}_{2}$ in air in serum-free medium MCDB 201 with appropriate supplements including bovine serum albumin, lipids, transferrin, epidermal growth factor, and insulin-like growth factor 1 . Primary cultures were established weekly using tracheas from three mice. As reported previously, ${ }^{11}$ each culture yielded approximately $2 \times 10^{6}$ cells at the second passage, thus providing sufficient cells for a single assay.

CELLULAR DETACHMENT ASSAY

To assess the ability of pollen diffusates to detach airway epithelial cells from their substratum, cells at the second passage were seeded in growth factor-deficient medium at $1.25 \times 10^{4}$ per well of a collagen coated 96 -well culture plate (Nunc, Roskilde, Denmark) for two hours, by which time $\geqslant 95 \%$ of the cells had attached to the substratum. The medium was then removed and diffusates were added to the wells in quadruplicate. Following incubation for four hours the wells were gently washed and fixed overnight with $10 \%$ phosphate buffered formalin. The proportion of cells remaining attached was assessed using a methylene blue dye binding assay. ${ }^{12}$ Briefly, cells were stained with $1 \%$ methylene blue in $0.01 \mathrm{M}$ borate buffer, $\mathrm{pH} 8.5$, for 30 minutes and washed three times in buffer. The bound dye was subsequently eluted with a 1:1 mixture of absolute ethanol and $0.1 \mathrm{M}$ hydrochloric acid and absorbances of individual wells were read at $650 \mathrm{~nm}$. Percentage detachment was calculated relative to the absorbance of wells incubated in basal medium. Cells incubated with $10 \mu \mathrm{g} / \mathrm{ml}$ of trypsin served as a positive control for the cellular detachment.

ASSESSMENT OF VIABILITY OF DETACHED CELLS The viability of cells detached by incubation with diffusates of Acacia and Lolium was assessed using trypan blue exclusion, compared with cells detached by $10 \mu \mathrm{g} / \mathrm{ml}$ of trypsin as a positive control. Because trypan blue exclusion underestimates the proportion of non-viable cells, the ability of the detached cells to survive in subculture was also assessed. For these experiments, diffusates were incu-

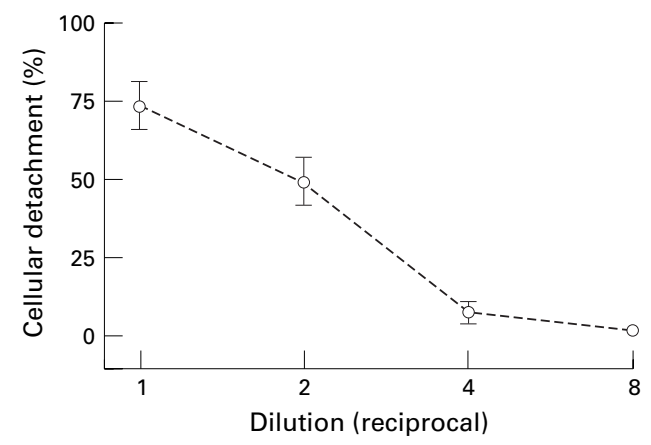

Figure 1 Effect of dilution of Lolium diffusate prepared using $100 \mathrm{mg} / \mathrm{ml}$ pollen on percentage detachment of murine airway epithelial cells from a collagen substratum. Data are mean (SE) of three separate assays.

bated for one hour with airway epithelial cells which had previously been seeded at $5 \times 10^{5}$ cells per well of a six-well culture plate. The detached cells were re-seeded in a 24-well culture plate and after 24 hours of incubation the number of attached cells was determined.

EFFECT OF PROTEASE INHIBITORS

Preliminary characterisation of the cellular detachment activity included non-selective inhibition of enzyme activity by the addition of newborn calf serum (Trace Biosciences, Sydney) to a final concentration of $10 \%$ as well as selective inhibition of proteases. ${ }^{13}$ For the latter experiments we compared the non-cytotoxic inhibitors aprotinin (Bayer) (an inhibitor of serine proteases), $\alpha_{1}$-proteinase inhibitor $\left(\alpha_{1}-\right.$ PI) (an endogenous antiprotease) (both from Sigma), and secretory leucocyte proteinase inhibitor (SLPI) (an endogenous inhibitor of trypsin-like enzymes) (R\&D Systems, Minneapolis, Minnesota, USA).

ANALYSIS OF DATA

To assess the statistical significance of any inhibitory effect, analysis of variance was performed for each assay followed by Newman-Keuls test for comparison between groups.

\section{Results}

Pollen diffusates of all species tested caused detachment of airway epithelial cells from their substratum. In separate experiments using different primary cultures of tracheal epithelial cells as targets, maximum cellular detachment by diffusates prepared with $100 \mathrm{mg}$ pollen per $\mathrm{ml}$ of basal medium varied between $30 \%$ and $90 \%$ (results from at least three experiments for each species of pollen). However, in a given experiment detachment by different pollens was of comparable magnitude even though the total protein concentration in diffusates prepared with an equal dry weight of pollen differed markedly between species (table 1). Detachment activity was related to the concentration of solute and diminished with serial dilution of the diffusate (fig 1).

Incubation with a $30 \mathrm{mg} / \mathrm{ml}$ diffusate of Acacia, which typically caused detachment of $30-60 \%$ of cells, yielded a population with approximately $50 \%$ viability as assessed by trypan blue exclusion. Upon re-seeding in 

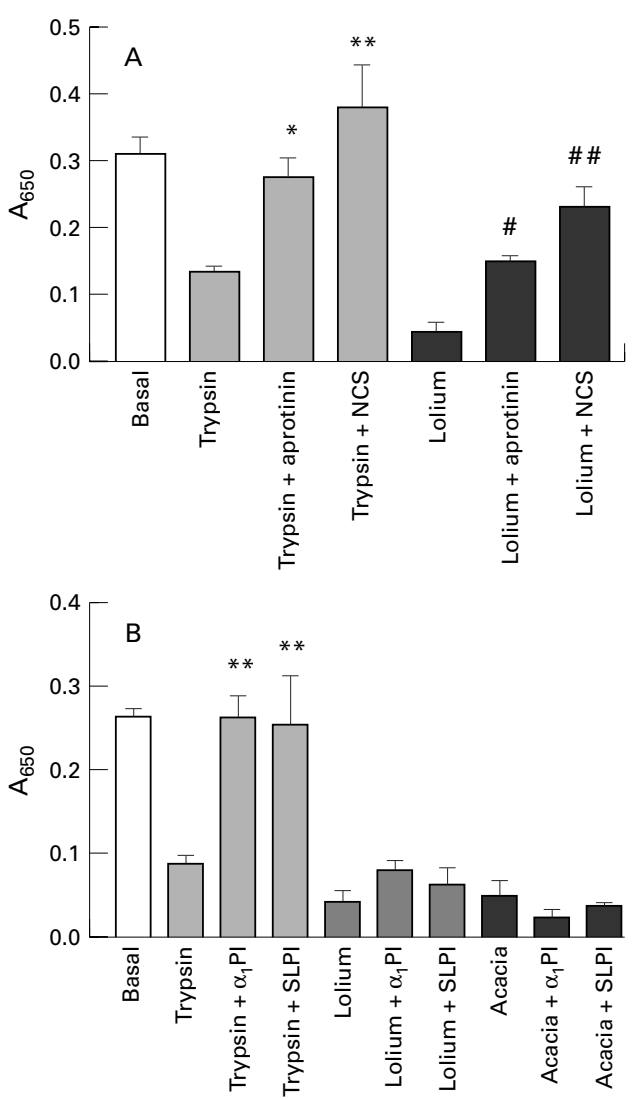

Figure 2 Effect of protease inhibitors on cellular detachment by trypsin or by pollen diffusates. $(A)$ Both aprotinin and newborn calf serum caused significant inhibition of detachment by trypsin $\left({ }^{*} p<0.05 ; \star \star p<0.01\right)$ and by Lolium diffusate (\#p<0.05; \#\#p<0.01). (B) $a_{1}-P I$ and SLPI completely inhibited cellular detachment by trypsin $\left(\star_{p}<0.01\right)$ but there was no statistically significant inhibitory effect of $a_{1}-$ PI or SLPI on Lolium or Acacia diffusate. In each case data are mean (SE) of replicates from a single assay.

culture approximately $20 \%$ of the detached cells re-attached and remained viable after a further 24 hours. In contrast, incubation with a $100 \mathrm{mg} / \mathrm{ml}$ diffusate of Lolium caused detachment of a similar proportion of the cells but all of these were non-viable, suggesting that this diffusate was cytotoxic. In comparison, incubation with $10 \mu \mathrm{g} / \mathrm{ml}$ trypsin detached all of the cells with $\geqslant 90 \%$ viability.

Cellular detachment by trypsin was substantially inhibited by $1000 \mathrm{U} / \mathrm{ml}$ aprotinin and wholly inhibited by $10 \%$ serum. Detachment activity in diffusates of Lolium pollen was partially blocked by aprotinin and almost completely blocked by serum in three separate assays (fig 2A). However, aprotinin had no effect upon the activity in Acacia pollen although serum inhibited cellular detachment by this diffusate (not shown).

Cellular detachment by trypsin was also completely blocked by incubation with $200 \mu \mathrm{g} /$ $\mathrm{ml} \alpha_{1}$-PI or $10 \mu \mathrm{g} / \mathrm{ml}$ SLPI. Although $\alpha_{1}$-PI caused modest inhibition of the activity of Lolium diffusate (fig 2B), this was not statistically significant in three of four assays. SLPI did not block the activity of Lolium diffusate (fig 2B), nor did it potentiate the inhibition by $\alpha_{1}$-PI (not shown). Neither protease inhibitor had any effect upon cellular detachment by Acacia diffusate (fig 2B).

\section{Discussion}

These experiments show that solutes released by a variety of allergenic pollens are able to cause detachment of murine airway epithelial cells from their substratum in vitro. We deliberately used an approach which recovered soluble components released after hydration without mechanical disruption because most of the solutes that are likely to be pathophysiologically relevant are released from the outer layers of the pollen grain within minutes of hydration and these constitute more than two thirds of the total extractable solutes. ${ }^{9} 10$ Prolonged extraction as is usually employed for studies of pollen solutes-for example, in hypotonic solution rather than a buffer of physiological osmolality, with stirring or grinding-liberates proteins from the inner layers of the pollen grain which might be less readily available to cause tissue injury.

Cellular detachment activity in the pollen diffusates was substantially inhibited by addition of serum and, at least in the case of Acacia pollen diffusate, permitted the detachment of a proportion of viable cells. It is therefore likely that activity is related to the action of enzymes in the pollen diffusates, most probably proteases. Nevertheless, pollen diffusates contain a variety of solutes and we cannot exclude a role for other components in causing detachment of airway epithelial cells. Indeed, non-enzymatic components probably account for the cytotoxicity that was observed. Activity was not simply a function of total solute release, as comparable cellular detachment was observed using diffusates which differed markedly in their total protein content. In this context it is of interest that the concentration of protein was lowest in diffusates of Acacia longifolia, as this is the only insect pollinated species among those tested. Whether this is also a characteristic of other insect borne pollens is as yet unknown.

Preliminary characterisation indicated that a component of the detachment activity in Lolium perenne diffusates was inhibited by aprotinin, suggesting the presence of a trypsinlike or chymotrypsin-like serine protease. Whether such a protease would be active in vivo is uncertain as the test system contained none of the endogenous antiprotease activities that might inhibit its activity. However, the diffusate could not be reproducibly inhibited by $\alpha_{1}$-PI which is a major endogenous antiprotease nor was it blocked by SLPI which is an inhibitor of trypsin-like proteases produced by airway epithelial cells that may complement the activity of endogenous $\alpha_{1}$-PI. ${ }^{14}$ Moreover, epithelial detachment by Acacia diffusates was not blocked by any of the selective inhibitors tested. These findings are of interest in the context of the recent isolation of novel serine proteases from the pollens of mesquite and ragweed. ${ }^{15} 16$ Although their ability to injure airway epithelial cells has not been studied, the peptidase recovered from mesquite pollen was not inhibited by any of the known endogenous mammalian antiproteases ${ }^{15}$ while the peptidase 
from ragweed could cleave and inactivate human $\alpha_{1}$-PI. ${ }^{16}$ Taken together with our observations of the relative lack of effect of endogenous antiproteases, these findings reinforce the notion that pollen derived proteases have significant potential to cause airway epithelial injury.

Using high concentrations of dithiothreitol activated Der $\mathrm{p} 1$ protein, Herbert et $a l^{6}$ demonstrated proteolytic disruption of canine airway epithelial cells and suggested that tissue damage in vivo could potentiate sensitisation to this antigen. The extent to which comparable injury by pollen derived enzymes might be relevant to allergen sensitisation is difficult to ascertain. However, very high local concentrations of pollen solutes (up to $50 \mathrm{mg} / \mathrm{ml}$ ) may be achieved when pollen grains are deposited on mucosal surfaces. ${ }^{9}$ In any case, epithelial denudation is not necessarily involved in increasing epithelial permeability because proteolytic enzymes may cause disruption of tight junction associated proteins. ${ }^{17}$ This could be tested using cells grown in culture well inserts, ${ }^{18}$ although we have encountered technical difficulties relating to the use of mouse tracheal epithelial cells.

If pollen proteases do contribute to epithelial injury and sensitisation, it is unlikely that this occurs in the lower respiratory tract as most intact pollen grains are likely to be trapped within the nasopharynx because of their size. Rupture of pollen grains can release granules of respirable dimensions which might facilitate access to more distal airways, ${ }^{19}$ although the enzymatic activity associated with such granules is undefined. Nevertheless, upper respiratory tract exposure would certainly be sufficient to cause sensitisation, and disruption of the epithelial barrier by proteases in pollens might promote sensitisation even to those pollen antigens which do not have intrinsic enzymatic activity.
1 McFadden ER, Gilbert IA. Asthma. $N$ Engl $7 \mathrm{Med}$ 1992;327:1928-37.

2 Holt PG, Britten D, Sedgwick JD. Suppression of IgE responses by antigen inhalation: studies on the role of genetic and environmental factors. Immunology 1987;60: 97-102.

3 Holt PG. Regulation of antigen-presenting cell function(s) in lung and airway tissues. Eur Respir F 1993;6:120-9.

4 Robinson C, Kalsheker NA, Srinivasan N, et al. On the potential significance of the enzymatic activity of mite allergens to immunogenicity. Clues to structure and function revealed by molecular characterization. Clin Exp Allergy 1997;27:10-21.

5 Arruda LK, Vailes LD, Mann BJ, et al. Molecular cloning of a major cockroach (Blattella germanica) allergen, Bla g 2 : sequence homology to the aspartic proteases. $7 \mathrm{Biol}$ Chem 1995;270:19563-8.

6 Herbert CA, King CM, Ring PC, et al. Augmentation of permeability in the bronchial epithelium by the house dust mite allergen Der p 1. Am 7 Respir Cell Mol Biol 1995;12:369-78.

7 Bass DJ, Wrigley CW. Pollen allergens around Australia: a survey of clinicians' experience. Med F Aust 1984;141:S1223.

8 Knox B, Suphioglu C. Environmental and molecular biology of pollens. Trends Plant Sci 1996;1:156-64.

9 Baraniuk JN, Esch RE, Buckley III CE. Pollen grain column chromatography: quantitation and biochemical analysis of ragweed pollen solutes. 7 Allergy Clin Immunol 1988;81: 1126-34.

10 Baraniuk JN, Bolick M, Esch R, et al. Quantification of pollen solute release using pollen grain column chromatography. Allergy 1992;47:411-7.

11 Kumar RK, Maronese SE, O'Grady R. Serum-free culture of mouse tracheal epithelial cells. Exp Lung Res 1997;23. $427-40$.

12 Oliver MH, Harrison NK, Bishop JE, et al. A rapid and convenient assay for counting cells cultured in microwell plates: application for assessment of growth factors. $\mathcal{f}$ Cell Sci 1989;92:513-8.

13 Storey RD, Wagner FW. Plant proteases: a need for uniformity. Phytochemistry 1986;25:2701-9.

14 Bingle L, Tetley TD. Secretory leukoprotease inhibitor: partnering alpha 1-proteinase inhibitor to combat pulmonary inflammation. Thorax 1996;51:1273-4.

15 Matheson N, Schmidt J, Travis J. Isolation and properties of an angiotensin II-cleaving peptidase from mesquite pollen. Am f Respir Cell Mol Biol 1995;12:441-8.

16 Bagarozzi DA, Pike R, Potempa J, et al. Purification and characterization of a novel endopeptidase in ragweed (Ambrosia artemisiifolia) pollen. f Biol Chem 1996;271: 26227-32.

17 Azghani AO. Pseudomonas aeruginosa and epithelial permeability: role of virulence factors elastase and exotoxin A. Am f Respir Cell Mol Biol 1996;15:132-40.

18 Devalia JL, Godfrey RWA, Sapsford RJ, et al. No effect of histamine on human bronchial epithelial cell permeability and tight junctional integrity in vitro. Eur Respir $\mathcal{F}$ 1994;7:1958-65.

19 Suphioglu C, Singh MB, Taylor P, et al. Mechanism of grass pollen-induced asthma. Lancet 1992;339:569-72. 